\title{
The haunted heart and the Holy Ghost: on retrieval, donation and death
}

Joshua Hordern

Harris Manchester College, Mansfield Road, Oxford, OX1 3TD, UK.

joshua.hordern@theology.ox.ac.uk, 01865 281479,@oxfordhvp,www.healthcarevalues.ox.ac.uk

Faculty of Theology and Religion, Harris Manchester College, Healthcare Values Partnership, University of

Oxford.

Word count: 10200

\section{Abstract}

This enquiry examines problems which haunt the "heart" and its donation. It begins by examining the heart's enduring significance for culturally mediated self-understanding, vulnerability to misunderstanding and abuse and relevance to challenging the determination of death by neurological criteria. Despite turns to brain-centred selfconceptions, the heart remains haunted by the hybrid experiences of identity accompanying organ transplant, the relational significance attached to dead hearts witnessed in the Alder Hey scandal and claims that heart transplants commonly constitute the legitimate killing of a person. To explore these phenomena, traditions are retrieved in which the heart-as-organ was construed in terms of a person's core identity. Influential Abrahamic beliefs about 'the heart' are considered in order to explore explanations for why the heart remains culturally preeminent, to make intelligible our haunted hearts and to examine possible violations of solidarity in organ donation practice. Jewish and Christian Scriptures are exegeted to illumine the sources of our haunting and address the desire for holistic bodily life. In these sources, the heart is the seat of affections, intelligence and agency but requires healing, conceived via the surgical metaphors of heart transplant and circumcision, if people are to join the insightful, solidary path of pilgrimage. Absent healing, the heart experiences a judgment of the whole person - organ-andcore - at the moment of death. Through such exegesis, the doctrine of the Holy Ghost emerges as a way to make intelligible, though not dispel, the heart's haunting. The doctrine's practical significance concerns the possibility of social unity among hearts, "intercordiality", which construes people within a covenantal life of pilgrimage which encourages heart donation in certain circumstances, makes intelligible the Alder Hey parents' experience of social misunderstanding and rejects ascribing any legitimacy in medical culture to the consensual killing of patients for the sake of retrieving their organs. 


\section{THE HAUNTED HEART}

This enquiry takes as its starting point four problems which haunt the "heart" and its donation. First, there are the experiences of distress and hybridity which recipients of transplanted hearts sometimes report. Second, there is the problem of the misunderstanding or underestimation, in some clinical and scientific contexts, of the significance of hearts to people. Third, there is the question of whether the death of the heart is coincident with the death of the person, along with any ramifications this has for the timing of organ retrieval. Fourth, there is the challenge of creating a culture in which hearts are freely donated. By way of response, the enquiry pursues an exercise in cultural archaeology with particular attention to Hebrew and Christian thought in order to provide an integrated interpretation of the heart's place in human life which can address practical problems around transplant and donation.

Three initial points specify further the enquiry's focus: first concerning the culture surrounding the heart, especially in relation to transplant; second, concerning the potential for abuse which misunderstandings of the heart's significance can occasion; and, third concerning the challenges posed by the heart to the practice of the determination of death by neurological criteria.

\section{Culture and the heart}

First, the heart steadfastly remains a focus for culturally mediated self-understanding. Through historical and literary investigation, Fay Bound Alberti has shown that, while 'the brain has come to be the organ par excellence of modern conceptions of interiority...embedded in our notions of selfhood, memory, imagination and the emotions', yet 'as a symbol of feeling and emotion, the heart is unbeaten' as the culturally accepted centre of affectivity and identity. As she notes, we do not send pictures of brains on Valentines cards.

Her diagnosis of the heart's continued cultural role is that

science has failed to conceptualize the meanings attached to the heart in ways that could make irrelevant, or replace, traditional beliefs about its emotional embodiment. The reason why this is so is that it has been constructed in opposition to, rather than in integration with, a holistic interpretation of the body. ${ }^{\text {ii }}$

Over against the brain, the heart remains a culturally preeminent way of representing the self, albeit a potentially ambiguous one. By saying, 'He has a good heart', the speaker may appraise health or praise character. Prima facie the ambiguity is whether "heart" refers to a material organ, or something immaterial, such as moral quality: two meanings apparently operating on quite different planes. Nonetheless, what is intended by 'heart' is normally not ambiguous but determined by either a biological or a metaphysical, ethical, or cultural frame of reference. Indeed, such is the disparity between these two kinds of meaning, due in large part to the predominance of brain-centred notions of personhood, it seems hard to see how they might intersect.

Bound Alberti describes this disjuncture as 'the heart of science that is a pump, versus the heart of culture'. iii Problematising any neat division, however, she also observes the strange meanings clustering around the heartas-pump, especially when it is transplanted. With Ali Mazrui, she thinks that, following transplant, a 'certain line from the Song of Solomon might assume a new haunting meaning. That dead person who donated a heart might cry with that famous line, 'I sleep, but my heart waketh' (5:2). . While not pursuing such Scriptural avenues' significance for organ transplants and the heart's affections, she notes the deficit of interaction between braincentred anthropologies and 'theology and ethics ${ }^{\text {si }}$ but leaves to others the challenge of excavating and deploying those texts, images and doctrines which have shaped and continue to influence civilizations from ancient times.

Shildrick et al. extend the analysis, observing how in

Western culture the human heart is perhaps the most symbolically significant of our organs. As both the putative seat of the soul and personal identity and the metaphorical symbol of love, it has multiple associations that exceed its strictly anatomical functions. 
In their approach, inspired by Merleau-Ponty's phenomenology, they note not only the predominant culture that 'organ transplantation constitutes an unproblematized form of spare part surgery in which failing biological components are replaced by more efficient and enduring ones" ${ }^{\text {vii }}$ but also that 'contemporary heart transplantation continues to be haunted by questions that cannot be answered by conventional research data' ${ }^{\text {viii }}$ Such haunting shows up in recipients' distress after transplantation. For example, one recipient said 'I felt I had an alien thing in me, or somebody else [sic] [heart].... I missed my old heart. ${ }^{\text {,ix }}$ While eighteen recipients interviewed initially described their transplanted heart as a machine 'with no further meaning', fifteen then displayed much more complex emotional responses including sobbing. More generally, recipients seem unhappy about the imposition of [donor] anonymity' along with 'strong connections to the donor both through the ubiquitous gift of life discourse that dominates transplant transactions' and 'through a sense of their embodiment becoming irreducibly hybrid. In biomedical terms, the donor's DNA, present in the transplanted heart, remains in the recipient's body for life, and may also circulate in the peripheral blood supply.' In short, 'the alien other is literally at the heart of the self. ${ }^{\mathrm{x}}$

Such observations conjoin genetic self-interpretations with everyday beliefs about the heart. Under that 'molecular optic' whereby genetic identity substantially defines the self, substantiation, transitioning from a distinct species member to a hybrid. A culturally ambiguous, quasi-social identity thereby haunts organ transplant. Just how this change in self-conception relates to organ recipients' original conception and gestation, as pre-natal recipients of DNA and blood supply, is screened out by these authors at least.

Shildrick et al., like Bound Alberti, note but eschew close attention to ancient beliefs about the heart, such as those found in millennia-old Jewish, Christian or Islamic traditions, which have engaged imaginatively in scientific investigation and humanity's complexly bodily, interdependent life. Such traditions' widespread influence on language and thought, through adherents and cultural legacy, provides a putative explanation for why the heart remains culturally preeminent amidst the developments which sciences such as neuroscience offer. Bound Alberti notes that 'Eastern and complementary practices [alongside]...theological or metaphysical explanations [of emotion causation via the heart or soul] continue to exist; they are simply not granted intellectual or academic status in the West'. ${ }^{\text {xii }}$ This bold account of 'the West' - always only doubtfully a single thing - is clearly neither a uniform nor necessary state of affairs, in a complex culture indebted both to longstanding theological traditions about the heart and newer brain-centred notions of human identity. Nor is there necessarily much overlap between explanations which hold academic status and everyday practice and belief. What remains underdetermined is whether traditional sources may make intelligible, if not dispel, the haunting which people experience regarding hearts and their donation. Without grasping the influence of such traditions, the suspicion will be that what haunts the heart is an imaginary ghost in a human machine, fixable by spare parts.

\section{Misunderstanding and abuse}

Second, understanding the haunting of the heart is more than a conceptual and historical matter or solely restricted to issues around transplantation but also sheds light on other practical problems. Consider, for example, the enduring relational significance attached to dead matter, including hearts, as associated with the identity of a person. Recall the testimony to this phenomenon borne by the Alder Hey parents, the remains of whose children, and especially their hearts, were retained by clinicians for research purposes, without appropriate consent, in a manner later judged deeply unethical. ${ }^{\text {xiii }}$ This abuse was then - astonishingly - repeated in the process of returning organs and tissue to the parents when researchers yet retained small samples of the same. Reflecting on this saga, theologian Michael Banner, former member of the Human Tissue Authority, comments that what is most striking is the 'opacity of the parents' concerns to the understanding of the hospital and... wider medical establishmentand even to bioethics in its dominant forms. ${ }^{\text {,xiv }}$ More generally,

bioethics is...incapable of making a contribution to overcoming the scientistic perspective and assumptions of current policy debates (inclined as they are, for example, to use 'emotional' as a pejorative). Bioethics...shares the presuppositions of that debate, and hence can have no heuristic role or therapeutic value in relieving the social misunderstanding which confronted the Alder Hey parents. ${ }^{\mathrm{xV}}$ 
This failure to grasp parents' affective attachments to their beloved children's body parts indicated a gaping hole in its imaginative world. To dismiss parents' affection for their deceased children's hearts as a mistake, as was common in the scandal's aftermath, testifies to problems which follow an incurious attitude to the intersection between the heart-as-organ and the heart-of-culture. A common if less pejorative response to the Alder Hay parents was puzzlement. For how could rational people attach such significance to dead matter for which neither their late children nor they could have any conceivable use? A considered bioethical review of the Redfern report which followed the Alder Hey scandal commented that

the desire to restore the integrity of the buried child or to make real what families imagined they had been doing at the time of the first burial should not influence an ethical position on the value of bodily integrity at death [or the inviolate nature of the dead]. On this question a very real range of views exists. ${ }^{\text {xvi }}$

In contrast to the Redfern report, and while acknowledging the significance, for some at least, of religious understanding of respect for the dead, this analysis casts doubt on 'the view that absolutely all fragments of a body must be reunited to avoid disrespect', xvii perhaps providing succour to those who retained dead children's body parts but also showing the deep cultural differences which any holistic interpretation of the body must deal with.

\section{Donation and death}

Third, there is the problem of the interrelation of brain and heart in the determination of human death, especially the haunting questions of what death is and when it occurs. Consider Miller and Truog's identification of conceptual deficiencies and cultural dishonesties in the way that determination of death by neurological criteria has operated. Healthcare culture is haunted by whether, when brain death has irreversibly occurred but while circulation and breathing continues (even by artificial means), the removal of vital organs leads to a person's death; or whether, the patient having died at the time of brain death, there is no person and no further death to come. Miller and Truog maintain that the so-called 'dead donor rule' (DDR), which requires patients to be declared dead before life-sustaining organs are removed for transplant, is doubly dishonest. First, it is dishonest in respect of Donation after Brain-stem Death (DBD), because 'most of the integrative functions of the body do not require brain function'. xviii Thus 'if patients currently diagnosed as brain dead are dead, then it is because they have lost the capacity for consciousness, not because they have lost the functioning of the organism as a whole. ${ }^{\text {,ix }}$ But they reject this account of death, considering Shewmon's evidence for 'somatic integrative unity ${ }^{\text {sx }}$ after braindeath. Their view is that the human being dies when the body ceases to function as an organism, which is marked by the irreversible cessation of circulation and respiration. ${ }^{\text {xxi }}$ Second, the DDR is dishonest in respect of Donation after Circulatory Determination of Death (DCDD) since we cannot know with certainty that a person is irreversibly dead at the time when organs are commonly retrieved and so cannot have confidence that retrieving organs is not killing a living person. Crucially, if they are not irreversibly dead then they are still dying, unless we think, on occasions when resuscitation is deployed, that we can raise the dead.

Miller and Truog want honesty that what organ retrieval commonly accomplishes is the killing of a person. Their bold view, however, is that this practice is legitimate both after brain-death and following pulselessness even if we do not know that death has irreversibly taken place. They seek a shift in cultural understanding so that, provided that there is consent, the retrieval of such individuals' vital organs is judged an acceptable way for humans to permit the ending of their lives. Here, as they recognise, a new problem emerges, namely that organ retrieval would constitute the legitimate killing of a person. Although continued integrative unity is not strictly speaking dependent on the heart but the circulation, Miller and Truog's approach threatens both the significance traditionally ascribed to the heart and the cultural self-understanding of much medicine, namely that killing patients is not legitimate.

\section{Cultural archaeology}

I will return to Truog and Miller's work but the goal here is not to mount a thoroughgoing ethical assessment of their accounts of irreversibility, permanence and intention. ${ }^{\text {xxi }}$ The approach instead is to undertake some cultural archaeology to retrieve traditions in which the heart as an organ was construed metaphorically and literally in terms of a person's identity. This strategy will reframe the haunting problems and social misunderstanding to 
which Bound Alberti, Shildrick et al. and commentary on the Alder Hey scandal attend. In so complementing, though not without awkwardness, the scientific evidence for 'somatic integrative unity' after brain death, it will also respond both to Bound Alberti's call for 'a holistic interpretation of the body' and to Truog and Miller's perhaps tempting recommendations for changes in medical culture.

The Abrahamic traditions are a good focus for such an exercise. For example, it was the Islamic scholar Ibn alNafiz who, in a thirteenth century common era commentary on Avicenna's Canon, reported his discovery of the pulmonary transit, the passage of blood from the right to the left ventricles of the heart via the lungs - a discovery which, while limited in scope, was a revolution in understanding the heart, overturning the accepted wisdom of Galen's classical anatomy. Moreover, it was al-Ghazzālī who particularly celebrated anatomy because 'it made man understand God's providence' in 'the wonderful structure of the human body'. xxii

The doctrine of providence, while variously understood in Abrahamic traditions, has been taken to suggest that while the organ and the self's identity may be distinguishable, they are not separable: once a human's anatomy incorporates a living heart, the death of that heart is the death of the person. ${ }^{\text {xxiv }}$ The heart beats spontaneously from human embryonic life's fourth week, yet remains fully dependent on the mother's pulse. From that time on, without any beating heart, a person would (barring mechanized replacement, whether briefly during a transplant or more permanently through life support) cease to have a basic feature of human identity, namely biological life, sustained by the heart through the circulation of blood. As the Jewish saying has it, 'the life of the flesh is in the blood' (Leviticus 17:11), a principle which applies as much to lambs as to people.

Encouragement to pursue this approach comes from two directions. First, Jurgen Habermas, a political theorist without religious affiliation, has sought to increase awareness of missing elements of public discourse. Taking a similarly troubling focus for ethical analysis, he observes how, following innovations in pre-implantation genetic diagnosis and genetic modification of embryos, getting 'used to having human life biotechnologically at the disposal of our contingent preferences cannot help but change our normative self-understanding. ${ }^{\text {xxv }}$ Such matters bespeak a weakness in non-religious ways of viewing our public life:

practical reason fails to fulfil its own vocation when it no longer has sufficient strength to awaken, and to keep awake, in the minds of secular subjects, an awareness of the violations of solidarity throughout the world, an awareness of what is missing, of what cries out to heaven. .xvi $^{-}$

While noting the important Islamic tradition of scientific enquiry and theological reflection there is a necessity to delimit the argument's scope in order to focus on traditions which have, to this point at least, had more influence on the Western culture about which Habermas is concerned. Accordingly, the focus here is to explore the imaginative world of the Hebrew bible and New Testament regarding the heart. Exploring traditional Jewish and Christian beliefs about 'the heart' provides a way to make intelligible both our haunted hearts and potential 'violations of solidarity' in the culture around organ donation.

To this end, the terms to be deployed are not Alberti's but rather the "heart-as-organ" and "heart-as-core". The former refers to what is ordinarily understood by biological science as the heart: that which beats and thereby sustains circulation. The latter operates more in the 'unbeaten' way to which Bound Alberti refers, denoting that which is at the seat of a persons' being and identity. A question is whether are there two things here - organ-andcore - or only one but under different aspects within a single, coherent, holistic account of bodily life.

Second, regarding the Alder Hey scandal, Banner commented that

In his study of the cult of relics, Peter Brown tells us that if we listen with sufficient care, we can find behind what may seem odd or disturbing, 'the strains of an alien music'. xxvii

Odd and disturbing currents do surround Alder Hey and organ donation. However, what seems alien may be more familiar than it first seems. That to which the Alder Hey parents witnessed is, Banner believes, somehow attuned to what has become strange to modern ears, some harmony of the human bodily, relational and spiritual constitution. Alien sources of our understanding of the heart, alien, that is, to much clinical and bioethical discourse and some everyday public consciousness, are perhaps more native than we may know, characterised, as one surprised former agnostic put it, by a beauty 'so old and so new'. xxviii Turning to texts of literature which 
have created the acoustic and intellectual space for influential notions of the heart across many civilizations (Western, Middle Eastern, African and South American among others), namely the Jewish and Christian Scriptures, is therefore sensible. These sources tend to be left unexplored, perhaps due to some embarrassment modern readers may have about their influence or to the assumption observed (though not apparently endorsed) by Bound Alberti that they should have no status at all. However, neither of these are humane reasons for not pursuing such analysis, especially in light of Alder Hey and Miller and Truog's culturally revolutionary recommendations.

\section{RETRIEVING THE 'HEART'}

So with this encouragement, we turn to the Jewish and Christian Scriptures themselves to endeavour a retrieval of the heart which illumines the sources of our haunting and addresses the desire for integrated, holistic bodily life. The following four steps cumulatively constitute such a retrieval, by showing how the imaginative distance between core and organ can be reduced and so disclosing the content of the these Scriptures which have had such a significant influence.

\section{The heart's intelligence, affections and agency}

First, it is a common scriptural topos that the heart-as-organ is represented as somehow intertwined with the heart-as-core in ways which avoid any such strong division as that between 'pump' and 'culture'. This integration, in which organ and core are not strongly separated but stably conjoined in humanity's bodily life, is articulated especially with regard to the affections which characterise the heart. ${ }^{\text {xxix }}$

For example, consider how the heart is described as fainting (Deuteronomy 20:3,8, Job 19:27, 23:16, Isaiah 1:5); melting (Deuteronomy 20:8, Joshua 2:11, Psalm 22:14, Nahum 2:10); trembling or shaking (Deuteronomy 28:65, Isaiah 7:2, Job 37:1); and staggering (Isaiah 21:4) - all deployed to suggest fear or horror; leaping out of its place in awe before God's mighty power (Job 37:1); becoming hot, suggesting anguish (Psalm 39:3) or like an oven, indicating anger (Hosea 7:6); beating wildly in anguish at the destruction of Judah (Jeremiah 4:19); throbbing (Psalm 38:10) in light of an awareness of God's discipline; being wrung, because of guilt or regret over rebellion (Lamentations 1:20); becoming hard, thus keeping out the word and Spirit of the Lord (Zechariah 7:12); failing in strength (Psalm 73:26); and yet healable through joy in covenant fellowship with God (Proverbs 17:22, Jeremiah 8:18); being strengthened physically by food (Judges 19:5, 8, Psalm 104:15). This last example has a correlate in the description of Israelite hearts consuming the Lord God and so living forever (Psalm 22:26; 73:26), an image fulfilled in the New Testament as believers' hearts are strengthened with grace through Jesus Christ the sacrificial lamb, whose death frees people to live hopefully accompanied by the Lord the Helper (Hebrews 13:5b-10) ${ }^{\mathrm{xx}}$, a hope embodied in bread and wine, received in the sacrament of communion. Taken together these texts and themes indicate integration rather than strong demarcation between the heart-as-organ - trembling, beating, throbbing etc - and heart-as-core, characterised by fear, anguish, joy and hope. xxxi Jeremiah's anguish at Judah's devastation is existentially and physically felt. The heart can be strengthened by food and by grace, sacramentally embodied.

More generally, the heart is associated with agency, affectivity and intelligence. Referring to the Hebrew bible, Lasater summarises by observing that

the heart was the governing center of thought, feeling, and action...The heart's condition determines the quality of moral agency. ${ }^{\text {xxii }}$

A person's core is thus represented as an organ which experiences transformations bearing directly on behaviour. $^{\text {xxxiii }}$ To thus co-locate affectivity, intelligence and agency in the heart is hardly uncontroversial or straightforward. 'Hebrew has no word for brain' xxxiv but instead the heart is the designated location for thinking, often articulated as 'saying in the heart'. The Greek Septuagint sometimes deploys terms to emphasise this such as $\delta i \dot{\alpha} \nu \circ \iota \alpha$ (dianoia), especially when referring to 'the thoughts of the heart'. A paradigmatic combination of these root terms, $x \alpha \varrho \delta i \alpha$ and $\delta i \alpha$ o $\iota$, occurs at Genesis 6:5, in God's judgment of the evil thoughts of people's hearts, linguistically echoed, in the Hebrew as well as in Greek, ${ }^{\text {xxv }}$ just before the death of David, the man after God's own heart (1 Sam 13:14) when he prays 
O Lord, the God of Abraham, Isaac, and Israel, our fathers, keep forever such purposes and thoughts in the hearts of your people, and direct their hearts toward you. (1 Chronicles 29:18)

While noting the obvious difficulty of interrelating these texts with discussion of the neurology of affection, intelligence and agency, or its interaction with cardiology, recall that we are endeavouring here a cultural investigation of the heart rather an exercise in neuroscience. ${ }^{x x v i}$ Moreover, making a definitive judgment as to whether and how the heart was metaphorically rather than literally conceived as the centre of 'thought, feeling and action' lies beyond this article's scope. Suffice to say that the evidence so far suggests a far closer cultural association between organ and core than that between pump and culture. ${ }^{\text {xxvii }}$

This matters for two culture-shaping calls which are central to Jewish scripture: first to 'Love the Lord your God with all your heart and with all your soul and all your strength', associated with the requirement that God's commandments are to be 'upon your hearts' (Deuteronomy 6:5-6); and second, to 'fear the Lord your God with all your heart and with all your soul, and to observe the Lord's commands and decrees' (Deuteronomy 10:12-13). Here as often elsewhere, 'heart' ( straightforward biological way to a beating organ. It has been common to think, drawing on parallels with Ancient Near Eastern sources, that the love which should fully characterise the heart is semantically exhausted by loyal actions obedient to the Lord's commandments, as a vassal 'loves' a suzerain. ${ }^{\text {xxviii }}$ Moran's account makes the heart inextricable with physical agency. Bearing in mind the way the heart functions in Hebrew Scripture as noted above, this clearly makes far less thinkable a neat distinction between a functioning biological organ which makes any agency possible and the person who is the originating centre of that agency.

However, if all that that the heart does when it loves is act, then it would bar the heart from being an integrative centre of affection, intelligence and agency, whereby the disposition of one's material condition (fainting, strengthened etc) was interwoven with the condition of one's heart (fearful, joyful etc) that in turn disclosed the objects of one love (idols, God etc). ${ }^{\text {xxix }}$ In short, while Moran's account rightly emphasises the heart's underpinning of agency, it does not accord with the fuller integration of agency and affection (heart-as-core) within the heart-as-organ indicated by the wider textual context analysed above. ${ }^{\mathrm{xl}}$

In summary, by imaginatively interweaving the heart's affections, intelligence and agency with the heart's physicality, the Scriptures depict a significant level of integration between the heart-as-core and the heart-asorgan.

\section{The heart's healing and pilgrimage}

Second, this exegesis is corroborated by the Hebrew bible's representation of the heart's failure and healing. Lasater observes that 'a number of texts envision the heart's frailty as a problem that can only be resolved through divine initiative. ${ }^{\text {xli }}$ The remedy, often articulated as an undivided or unimpaired heart, permeates the Jewish Scriptures. Consider Yhwh's promise to 'give them one heart and one way, that they may fear me forever, for their own good and the good of their children after them.' (Jeremiah 32:39) Here 'Israel's heart is too deeply flawed to generate proper action on its own, requiring Yhwh unilaterally to give them one heart and one way to ירא [fear] me always. ${ }^{, x l i i}$ The heart's unification brings right agency and a proper fear of God, indicating a proper love of God. Similarly the Psalmist sings:

Teach me your way, O Lord, that I may walk in your truth; unite my heart to fear your name.

I give thanks to you, O Lord my God, with my whole heart, and I will glorify your name forever. (Psalm 86:11-12)

Here 'the speaker petitions Yhwh to enable proper moral agency by granting unity to a human heart impaired by division. ${ }^{\text {xliii }}$ The unification of the heart is associated with proper affection (fear) that can correct 'impaired moral agency'. xliv In short 'the לבב [heart] [is] a flawed organ that...yields disordered thoughts and desires - thoughts and desires that are gauged according to an exterior, normative standard. ${ }^{\text {xlv }}$ In speaking of the Lord's 'way', Psalm 86 'presents divine law or instruction almost medicinally as that which heals the heart's disorderly 
fragmentation. ${ }^{\text {,lvi }}$ A similar image describes the heart as growing sick (Proverbs 13:12, Jeremiah 8:18, 17:9, Lamentations 5:17) and so requiring healing. There is an expectation of grace for the heart and a desire for God to do a new thing in the heart, focused especially in the language of the 'clean' (or pure) heart: 'Create in me a clean heart, O God!' (Psalm 51:10).

Lasater's summary of this underlying motif is worth quoting at length:

To call for divine transformation of certain bodily organs was one way that Second Temple period texts spoke about sin as a problem of human nature from which people needed to be freed... What often expressed such conceptions of sin were metaphors of God's transforming bodily organs, especially the heart. This metaphorical tie to bodily organs exemplifies how some scribes in the Second Temple period were already conceptualizing sin not just as moral agents' misdeeds, but more fundamentally as the condition that cultivates misdeeds and requires treatment. This talk of transforming organs commonly appears alongside an emphasis on divine instruction or law. slvii

This analysis focusses on the possibility of the healed heart guiding agency aright. Proverbs in particular articulates a unity of heart and agency: 'Above all else, guard your heart, for everything you do flows from it.' (Proverbs 4:23) 'As water reflects the face, so one's life reflects the heart.' (Proverbs 27:19) Actions flow from the heart. Life is a reflection of the heart. The heart's reasons are commonly imagined in liquid terms: 'The purposes of a person's heart are deep waters, but one who has insight draws them out.' (Proverbs 20:5) 'In the Lord's hand the king's heart is a stream of water that he channels toward all who please him.' (Proverbs 21:1) So the heart's reasoning is not arid but drenched with personal and public purposes and expectations. Moreover, its direction is conceived within the providential, gracious presence of God: 'In their hearts humans plan their course, but the Lord establishes their steps.' (Proverbs 16:9) Human planning (practical reasoning) and establishing the steps (providential divine action) are united without elision. Practical reasoning and action are in turn bound up with material realities since the life-force of the circulatory system which is 'in the blood' works through reasoning and agency to make a material difference in the world, just as water flows from a spring, shaping a channel. The heart-as-organ is thus interwoven with intelligence, affections and agency associated with the heart-as-core. That agency then goes on to shape the life and culture of the visible world.

This raises a further question, namely in what direction the heart should channel agency. The Psalmist sings: 'Blessed are those whose strength is in you, whose hearts are set on pilgrimage. (Psalm 84:5) And yet Israel's history is of hearts not following the right path: 'For forty years I was angry with that generation; I said, 'They are a people whose hearts go astray, and they have not known my ways.' (Psalm 95:10) The heart and the direction of the feet are here conceived together as one integrated movement. Pilgrimage on the path is the right orientation of the heart. But when hearts go astray, the people walk in the wilderness. The heart's orientation directs the movement of the people, conceived as a collective. The New Testament extends the thought in the motif of following Christ, fulfilling both the call to love God with a heart wholly set on pilgrimage, and Moses' unusual experience of intimate friendship. In the beatitudes, the pure in heart are blessed who, having followed Christ on their pilgrimage, will come to see God (Matthew 5:8). Similarly, Jesus is recorded as teaching that 'where your treasure is, there your heart will be also', attached to the injunction to store up treasure in heaven through works of generosity (Luke 12:34). As the eye is singly oriented to God, so the heart will have a single orientation, organizing its practical reasoning towards love of God and neighbour, thereby fulfilling the Old Testament's law and prophets' depiction of the heart's integration of affections, intelligence and agency. However, far from being an optimist about human capacities to live like this, Jesus is said to have observed that it is from the heart that all kinds of injustice and evil proceed (Mark 7:17-23). In so doing, he echoes the Jewish theme of the deceptiveness (Jeremiah 17:9) and hardness of hearts, ascribed both to Pharaoh (Exodus 9:12) and the wandering Israelites (Psalm 95:7-11), applying it to the condition and conduct of his contemporaries, especially the Pharisees and teachers of the law (Mark 7:6-8; citing Isaiah 29:13).

By interweaving metaphors of heart failure and transformation with moral agency and practical reasoning, these texts bear further testimony to the integration in Jewish and Christian thought of what might seem to be divergent, namely the heart-as-organ and the heart-as-core. The integration works by imaginatively construing as one the organ and the agency of the person, drawing together the vital life function which the organ sustains with the purposes of the heart in agency which a person pursues. This integration, in which the heart is the source of 
agency which affects the culture of a people - whether ancient Egypt or second Temple Judaism - makes even more unthinkable any strong distinction between organ and core or indeed 'pump' and 'culture'.

\section{The heart transplanted and circumcised}

Third, the unsettling of a modern disjuncture between pump and culture through the imaginative integration of organ and core in the Hebrew and Christian scriptures comes to a double climax in two striking surgical motifs. First, there is heart transplant:

And I will give you a new heart, and a new spirit I will put within you. And I will remove the heart of stone from your flesh and give you a heart of flesh. And I will put my Spirit within you, and cause you to walk in my statutes and be careful to obey my rules. (Ezekiel 36:26-27; cf. 11:19-21)

In context, what is sought is the renewal of the covenant between God and the people, made manifest in the people's obedient pilgrimage. This requires replacing a stone-dead heart with a living one, filled with the Spirit's energy. In New Testament thought, this gift is the Holy Spirit or the Holy Ghost, to whose significance for the heart's haunting we will return. For now, note that at the core of the founding story of Jewish and Christian civilisation lies heart transplant, arguably shaping a cultural imagination which surrounds and, at times, resists a culture of treating organs as spare parts or mere dead matter.

Second, there is the injunction to 'circumcise the foreskin of your heart' (Deuteronomy 10:16). This alien strain for many moderns' ears is deeply physical in its imagery, uniting heart and agency, while at the same time clearly impractical as a surgical procedure. Its bearing on integrated moral agency emerges in the promise that

the Lord your God will circumcise your heart and the heart of your offspring, so that you will love the Lord your God with all your heart and with all your soul, that you may live. (Deuteronomy 30:6)

These words promise a way to wholehearted obedience for all, not just those males marked by surgery. True membership of the covenant community requires completely committed love (Deuteronomy 6:5), in which the whole person's whole life is fully marked out by covenant faithfulness, indicating a complete integration of ritual purity, moral psychology and behaviour. ${ }^{\text {xlviii }}$ The quality of the 'heart-as-core' is imaginatively rooted in the heartas-organ as the integrative focus for all that God requires of a person. xlix And yet, while heart circumcision figuratively unites heart-as-core and heart-as-organ, conjoining flesh, purity and obedient agency, the imagery only works by proposing an impossible physical procedure, thereby conceptually distinguishing, while not wholly separating, the core from the organ again.

Complementing these last two points which have focussed on the heart's healing and surgery, further building a cumulative picture of the complex integration of organ and core, a final focus indicates how hearts which refuse such remedies meet with death.

\section{The judgment of the heart}

Fourth, then, the condition of the heart-as-core, disclosed in a person's affections and agency, is predictive of the fate of the heart-as-organ. References to the heart as an organ which can be damaged, while rare in the Hebrew Scriptures, commonly draw a connection between the core's sinful condition and the organ's death. Such hearts become a focus for judgment, embodying as complete an integration as possible of core and organ.

The paradigm case concerns the death of Absalom, King David's rebellious son. Indeed, the interrelation between the hearts of Absalom, David, the Israelites and God illustrate well the Jewish Scriptures' general representation of the heart. In the narrative, David becomes king once marked out by the prophet Samuel as 'a man after [God's] own heart' (1 Samuel 13:14). Absalom, beloved by his father, yet rebels against him and, by standing at the city gate and intercepting those seeking justice from David, 'stole the hearts of the men of Israel' (2 Sam 15:4-6), who then deploy their agency over against David and in aid of rebellion. The story's denouement comes when Absalom, in flight from David's men, is knocked from his steed by a branch and left hanging, perhaps by the very long hair by which his beauty was most characterized. Coming upon him, Joab, even though he knew how 
much David loved his son, 'took three javelins in his hand and thrust them into the heart of Absalom while he was still alive in the [heart of the] oak.' (2 Sam 18:14) Here Absalom's heart-as-organ is the focus for a judgment attracted by the division of his heart from David's and thus from God's which in turn divided the people's hearts from the king. Inasmuch as the oak tree itself becomes the scene of Absalom's downfall, even the heart of nonhuman creation assists in the judgment on Absalom's heart.

This pattern is repeated in respect of the corruption of Joram. Jehu is commissioned to bring Joram's evil rule to an end. Accordingly, Jehu 'drew his bow with his full strength, and shot Joram between the shoulders, so that the arrow pierced his heart, and he sank in his chariot.' (2 Kings 9:24; see also Psalm 45:5) The Lord consequently commends Jehu for carrying out 'all that was in my heart' (2 Kings 10:30), leading the reader to contrast David's and God's heart with the fate of Joram's heart. In both cases, the fate of the heart-as-organ is contingent upon the judgment on the quality of the heart-as-core. The termination of the biological heart's functions is wholly due to the character of the life which that heart sustained. The integration of core and organ in human hearts becomes totally illuminated only at the moment of death, when the heart beats its last.

\section{What has been retrieved?}

What "heart" has been retrieved by this exercise in cultural archaeology? From genres of law, song, prophecy, lament, history, wisdom and narrative, what has emerged is a coherent if multifaceted integration between heartas-organ and heart-as-core. In summary, the heart is the seat of affections, intelligence and agency; but it requires healing if people are to be set rightly upon the path of pilgrimage to God; membership in the community of such pilgrims is conceived in the surgical metaphors of heart transplant and circumcision; but without such healing, pilgrimage, transplant and circumcision, a person's heart faces a judgment of the whole person - organ and core together - in which their total integration is disclosed at the very moment of death. Such exegesis demonstrates the heart's integrative function in the Scriptures' thought-world. In contrast with the brain-centred thought-world which produced neurological criteria for the determination of death, (recalling Miller, Truog and Shewmon's critique of such DBD and its underpinning philosophy) the heart's death, terminating the life-giving circulation of blood, is presented as coincident with the end of a person's life.

It seems plausible that these Scriptures' powerfully metaphorical yet inescapably corporeal presentation of the heart, woven into cultures both Jewish and Christian over millennia, has forged key aspects of the linguistic, artistic and conceptual context that has made the heart unbeatable, in the way Bound Alberti suggests. Globally speaking, these ancient sources' representations of the heart continue to be communicated from one generation to another in manifold forms, not least through the adoption of Scriptural phrases and thought-forms in the vernacular of European languages. However, in some cultures the heart is now left strangely haunted, as ancient thought-worlds become less commonly understood yet still appear, seemingly inexplicably, in the everyday attitudes of people towards and speech about bodily organs, such as parents towards deceased children's hearts and those receiving hearts towards donors.

\section{HAUNTING AND THE HOLY GHOST: GIVING OUR HEARTS AWAY}

Accordingly, this retrieval offers ways to make intelligible, though not necessarily dispel, the haunting problems which surround Bound Alberti's distinction between pump and culture, brain-centred notions of personal identity, the Alder Hey parents' concerns and Miller and Truog's approach to the death of persons, including their bold conclusions concerning the legitimacy of the removal of organs from living people.

The haunting may begin to be rendered intelligible by attending to the doctrine of the Holy Ghost, the breath of God in creation (Genesis 1:2). In Hebrew thought and especially in the later highly influential Christian tradition, it is the Spirit's salvific activity, taking form in divine love, which is vital to that transplant and circumcision which can heal the heart's affections, intelligence and agency, and set persons on the active, integrative, social path of hopeful, solidary - not solitary - pilgrimage.

In the New Testament, the Holy Ghost (or Spirit) is depicted fulfilling the elements of Jewish expectation concerning the heart discussed above. As to agency, intelligence and affection, the Spirit brings guidance into all truth (John 16:13) along with the fruit of holy affections and power for an active life of obedience (Galatians 
5:13-26). As to healing and pilgrimage, the Spirit brings freedom from the heart's troubles (John 14:25-27; cf. John 14:1) and leads pilgrims on the way to their heavenly Father (Romans 8:14-17). As to transplant, the Spirit fulfils the prophecies of Jeremiah and Ezekiel: in Paul's words, 'hope does not put us to shame, because God's love has been poured into our hearts through the Holy Spirit' (Romans 5:5). As to circumcision, covenant membership, which unites many persons into one community of peace, is determined not by outward circumcision but by circumcision of the heart by the Spirit (Romans 2:29). As to judgment on the heart, the Holy Spirit is specifically commissioned for that task (John 16:8-11).

For both Hebrew and Christian thought, then, the Spirit of God or Holy Ghost is the appropriate framing consideration for addressing the problems of the haunted heart discussed above. Reframing the heart within the Hebrew doctrine of Spirit-inspired creation and the specifically Christian doctrine of the Spirit indwelling the heart offers complementary ways of understanding the unity between persons and of responding to the unsettling practical questions which surround certain clinical practices. Moreover, such an interpretation of what makes humans tick in their relationships makes it easier to understand why the heart remains preeminent as a symbol of human identity and solidarity.

To see the cultural and practical significance of the Spirit, consider three developments of the above retrieval of the heart under the following headings: "intercordiality"; pilgrimage and donation; and transplant and death.

\section{“Intercordiality"}

First, this understanding of the Spirit in human life suggests a social theory such that the transplant of a heart from one person to another constitutes not a transfer of spare parts but an interweaving of organisms who are spiritually united through a single creation and who are thus imbued with an understanding of their hearts, however inchoate, as at the core of their identity, that focus for agency, affections and intelligence which the Hebrew and Christian scriptures attest. The neologism 'intercordiality' is apt to this created social unity of hearts and persons, which is at odds with language or practices which represents donors and recipients as engaged in a purely mechanical process. Clearly the mechanical functioning of the transplanted heart matters for the success of an operation but it does not exhaust the meaning of the transplant itself, as the evidence of the recipients themselves indicated.

On the one hand, such a theory, culturally embedded over centuries and inflecting recipients' sense of their experience at a residual level, makes intelligible organ recipients' experiences of hybridity by deploying a lens which integrates biology and identity in community, allowing also for that molecular optic which conceives hybridity primarily as the mingling of DNA. This aspect of the heart's haunting would be made yet more intelligible by the idea that recipients, sharing the same species with donors, anticipate in their post-transplant bodily constitution both the union of hearts for which human persons are destined and the new heart of which Jeremiah wrote. Coming to conscious awareness of this social reality would also offer relief for the haunting which some recipients experience. For the sense of an alien presence is only haunting if others are conceived as fundamentally different rather than as neighbourly kin: one people originally created by Spirit who are called again to oneness by the same Spirit, a oneness which heart transplants strangely prefigure.

On the other, applied at a familial leve but on the same cultural basisl, a social theory of intercordiality makes intelligible the experiences of the Alder Hey parents who recognise their children's identity in the hearts and tissue of those little ones, loved and lost. Biomedicine's representations of hearts-as-organs cannot erase the hearts' affective resonance or the equation of beating and (even) once-beating hearts with personal presence. Much bioethics' failure to endorse the affective significance of bodily integrity is bound to overlook the significance of the attachments which exist between parent and child, and especially the pre-natal social union between mother and child. The intercordiality of their lives then, embodied in the umbilical cord, ${ }^{\text {li }}$ as one heart sustains another, is the life-course's earliest witness to the social unity, to which the Jewish scriptures witness respect of the Spirit's work in creation.

Intercordiality is thus the opposite of the heart turned in on itself (incurvatus in se), for which healing and heart transplant is necessary. The incurvatus image, made famous by Augustine and Luther, diagnosed a malady in human life whereby human hearts turn away from each other, denying the possibility of a unity of intelligence, affection 
and agency which might build a common life, marked by sharing goods in common and self-donation in love of others. The positive vision of intercordiality is of a social body of people who were 'of one heart and mind' (Acts $4: 32)$,

a community, where there is no love of a will that is personal and, as we may say, private, but a love that rejoices in a good that is at once shared by all and unchanging - a love that makes 'one heart' out of many, a love that is the wholehearted and harmonious obedience of mutual affection. . $^{\text {li }}$

Such a community, Augustine thinks, is prefigured in the social unity which characterises humanity as a species, sharing a common heritage traced to the Spirit's creative work. However, it can only be firmly established and maintained by the grace which inaugurates a new community, the body of Christ, brought to life by the Spirit.

In this community, the intercordiality of many people with one heart is made possible by a love poured out in their hearts by the Holy Spirit.

Seen in this light, donation and transplant are not transactions of spare parts between individuals but existential recognitions of common species membership and humanity's ultimate vocation to a peaceful communion with one another and with God. The incurvatus in se echoes Habermas' concern about 'the violations of solidarity throughout the world ${ }^{\text {liii }}$ which threaten the practice of heart donation. The heart turned in on itself will not think to give any vital organs - still less the heart - to others; but the heart turned outwards in intercordial love will be freely given.

\section{Pilgrimage and donation}

To Second, to sustain such love, the Spirit inspires not only intercordiality but a life of covenantal pilgrimage. In Christian thought, solidarity is expressed in an enduring covenantal community inaugurated by the Holy Spirit uniting people with God and one another. The divine heart, disclosed in the Jewish Scriptures, comes close in Christ's incarnation, creating a new covenant sealed in his life-blood, uniting his body's members, each marked by a transplanted and circumcised heart into which love is poured by the Spirit. In short, God's love takes a concrete form in a human person with a human heart. Through that person all human hearts may come into loving unity. Crucially, for practical purposes, this incarnate participation in human experience does not end with death itself but rather with the renewal of bodily life, including the heart-as-organ, through resurrection. Instead of an expectation of an immaterial afterlife, there is a confidence that the physical constitution of humanity will be given back again to human persons in a new heaven and a new earth.

The New Testament description of the life of those entering this covenant community is peregrinatio, or

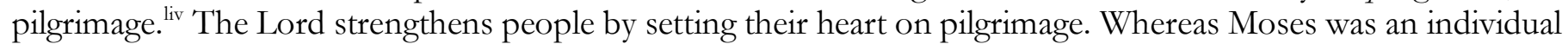
journeying with God as with a friend, and the people of Israel were desert wanderers, the possibility which Christian theology attests is that human hearts may beat in time with each other on the journey towards the presence of God. What the new covenant inspires is a binding together of hearts in union - the heart of God with the hearts of people which are bound with one another on pilgrimage: intelligence, affections and agency united as one, within individuals and between people. The peregrinatio motif also implies that the heart-as-core, the seat of a person's being, continues beyond the temporal end of the human journey at death and into resurrection - the peregrine heart is at rest with God beyond death while awaiting the holistic embodiment of resurrected life. Though the heart-as-organ may cease to beat, though circulation may end, the heart-as-core awaits a reintegration with a new organic heart and flesh. While the heart's death is not the final end of any person, nonetheless, that death requires a severing - for a time - of the hitherto inextricable association of organ and core. Bound Alberti's call for holistic interpretation of the body finds its Christian theological answer in the resurrection of the (re-)embodied heart.

Such future hope, guaranteeing a fully restored bodily life, has the power to free people to give themselves to others now. Such self-gift includes, in principle, the donation of the heart, organ and core, in solidarity with and in service of others. With the Spirit's heart transplant comes the freedom to give one's heart away, a vision which can both inspire and make intelligible a culture of organ donation. 
Third, the haunting question remains as to the practical and cultural significance of the heart for the determination of death and the proposed practice of retrieving organs from the living. The scriptural thought-world provides ways to make intelligible an integration between organ and core such that the continuing circulatory life of the blood within a person represents the continued existence of the person. When the heart dies, the person dies. If the life is in the blood it is only when circulation stops that life ends. A strong implication of this Jewish and Christian thought-world and symbology is that only the final loss of circulatory and respiratory function constitutes the death of the person. Theological conceptions of this integration of organ-and-core and of 'intercordiality' clearly do not bear directly on whether the heart's death in any given case is irreversible or permanent. That is not their competence. Nonetheless, such conceptions clearly have significant consequences for organ retrieval and donation practices in general. ${ }^{\text {lv }}$ Giving one's heart away is properly 'intercordial' but would only be right according to the practice of 'donation after circulatory determination of death' (DCDD). It would represent a kind of posthumous pilgrimage of a heart upon ceasing to sustain one particular life and en route to sustaining another, a last testimony to present intercordiality and future resurrection: 'I sleep, but my heart waketh' (Song of Solomon 5:2).

Such a vision runs counter to much prevailing clinical culture. While the idea of 'a head transplant is anathema', ${ }^{\text {, vi }}$ the still beating heart of a person following brain death is still commonly been considered as a spare part to be retrieved. The argument here corroborates Mauthner et al.'s call to 'eliminate the rhetoric of the machine model' and revisit the informed consent process...to include information about the potential risk of identity disruption. Ivii But it also emphasizes the importance of engaging sensitively in cultural and religious interpretations of the heart in that process, where appropriate. ${ }^{\text {Iviii }}$

Less commonly, once dead, hearts have been retained by deceit. Following the Redfern review of the Alder Hey scandal and Miller and Truog's critique of DBD, this may be ascribed to a mix of bad culture and dishonest philosophy. ${ }^{\text {lix }}$ However, a challenge to pose to Miller and Truog's account concerns the kind of culture concerning death and the heart which their perhaps tempting proposal would create. For they would prefer to develop the practice of organ retrieval which kills a person rather than follow the scientific work of Shewmon to the conclusion that Robert Spaemann draws, namely that a living person is still present following brain death, someone who should be protected from harm rather than something from which spare parts may be harvested. ${ }^{\text {lx }}$ Consent for this to happen does not alter the kind of violation of human dignity and solidarity which such a practice would entail. Even if Miller and Truog are right about the uncertainties which surround irreversibility in DBD and DCDD, then this certainly does not license their view of consent-based killing for the sake of the otherwise legitimate and loving practice of the heart's donation, retrieval and transplant. The notion that the consent to be killed is sufficient to license such a view is made appealing by referring, understandably, to the benefit of the recipient. However, the cost is high, namely the collapse of the heart of a medical culture long resistant to the deliberate killing of patients.

From the perspective of the Jewish and Christian Scriptures, it is salient that the integrative functions within the human body which continue after the loss of all but peripheral brain functions depend in large part upon the heart's maintenance of circulation. The account of common creation and species solidarity recognises how the organ and the core of the person, which the heart constitutes, sustains biological personal life, even without continuing agency, intelligence or even any obvious affectivity. This grounds the vocation to a solidary, intercordial covenant to be maintained until the breath of life departs.

Any such covenantal culture of social togetherness will be hard-won since the quality of the heart, deceptive above all things, is itself always a threat to the intercordiality to which humans are called. Lives lived in covenant pilgrimage will keep company both with those needing a heart transplant and those whose life, whether lacking consciousness because in utero or suffering brain death or even living in the womb of a woman who has suffered brain death, yet continue to be sustained in that kind of integration possible to them at that stage in their pilgrimage. With such persons, all have ties of 'inviolable solidarity'.

It is hardly convincing to sacrifice such solidarity in light of significant uncertainty about reversibility, albeit for the sake of those on transplant waiting lists. To argue from ignorance about the precise timing of irreversibility towards a claim that donors, knowing that they would still be living, should be permitted to consent to be killed, 
is to unweave the intercordiality of kindly accompaniment upon which a decent society and medical culture should be based. If that means a diminution of the stock of organs available for transplant, then this is a cost to be borne for the sake of the solidarity unto death which we should have one with another. Miller and Truog's bold recommendation to transform the heart of medical culture point to another route forward, but not one which should count as progress. In this, Miller and Truog seem to be in line with the spirit of the Alder Hey researchers for whom the clinical imperative trumped other less tangible cultural concerns.

\section{CONCLUSION}

In conclusion, whether one views the Alder Hey parents as mistaken, marginalises the hybrid experience of organ recipients and rejects Jewish and Christian anthropology as a cultural hangover or, alternatively, pursues a thoughtful, practical revision of brain-centred conceptions of personhood is for the reader to decide. The argument here is that the concerns we have about the heart are haunting because of their relative unintelligibility vis-à-vis brain-centred conceptions of personhood which have become predominant in much clinical culture. The discussion of influential ancient cultures, texts and ideas endeavoured here has suggested that these concerns become more intelligible and may be effectively addressed when seen in the light of Jewish and Christian thought. 


\section{ACKNOWLEDGEMENTS}

I acknowledge the support of the Ashmolean Museum, especially Dr Jim Harris, for first making me think about this topic. I also gratefully acknowledge funding from the Sir Halley Stewart Trust which supported the initial conference that lay behind this collection of papers. The views expressed are those of the author and not necessarily those of the Sir Halley Stewart Trust. The comments of two anonymous reviewers were also very helpful in improving the argument.

\section{PATIENT AND PUBLIC INVOLVEMENT}

No patients were involved in this research.

i Fay Bound Alberti (2010), Matters of the Heart: History, Medicine, and Emotion (Oxford: OUP), 155-156.

ii Bound Alberti, 167-68.

iii Bound Alberti, 166.

iv Bound Alberti, 1; citing Ali Mazrui (1968), "The Poetics of a Transplanted Heart", Transition 35, 51-59, 56.

v Bound Alberti, 13.

vi Bound Alberti, 141.

vii Margrit Shildrick et al. (2018), "Messy Entanglements: Research Assemblages in Heart Transplantation Discourses and

Practices", Medical Humanities 44:1, 46-54, 46.

viii Shildrick et al., 47.

ix Oliver Mauthner et al. (2015), "Heart Transplants: Identity Disruption, Bodily Integrity and Interconnectedness", Health 19.6: 57894, 587. Mauthner et al. review extensive literature about post-transplantation distress while also exploring other complex recipient responses drawn from their own qualitative work.

x Shildrick et al. 48-49.

xi Carlos Novas and Nikolas Rose (2000), "Genetic Risk and the Birth of the Somatic Individual," Economy and Society 29:4, 485-513.

xii Bound Alberti, 154-55.

xiii The Royal Liverpool Children's Inquiry Report (The Redfern Report) (2001), London: The Stationery Office.

xiv Michael C. Banner (2014), Ethics of Everyday Life: Moral Theology, Social Anthropology, and the Imagination of the Human (Oxford: OUP), 156.

xv Banner, 157.

xvi Steve Dewar and Paula Boddington (2004), "Returning to the Alder Hey Report and Its Reporting: Addressing Confusions and Improving Inquiries", Journal of Medical Ethics 30:5, 463-469, 467.

xvii Dewar and Boddington, 465.

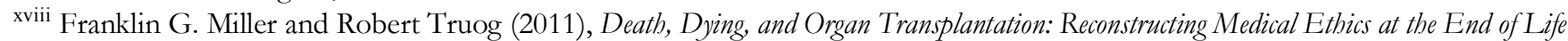
(Oxford: OUP), 65.

xix Miller and Truog, 68.

xx Alan Shewmon (2001), “The brain and somatic integration: Insights into the standard biological rationale for equating 'brain death' with death", The Journal of Medicine and Philosophy 26:5, 457-478.

xxi Miller and Truog, 78.

xxii Miller and Truog, esp. chapter five and the discussion with Bernat.

xxiii Peter Pormann (2013), The Mirror of Health: discovering medicine in the golden age of Islam (London: Royal College of Physicians).

xxiv Robert Spaemann (2011), “Is Brain Death The Death Of A Human Person?” Communio 38, 326-40

xxv Jurgen Habermas (2003), The Future of Human Nature (Cambridge: Polity Press), 72.

xxvi Jurgen Habermas (2010), "An Awareness of What is Missing", in An Awareness of What is Missing: Faith and Reason in a Post-Secular Age (Cambridge: Polity Press), 19.

xxvii Banner, 173; citing Brown, Peter (1981), The Cult of the Saints: Its Rise and Function in Latin Christianity (Chicago: University of Chicago Press), 108.

xxviii Augustine (1998), Confessions, tr. H. Chadwick (Oxford: OUP), 10.xxvii.38.

xxix For discussion of 'affections', see Joshua Hordern (2013), Political Affections: Civic Participation and Moral Theology (Oxford: OUP).

xxx Translations here and throughout are English Standard Version unless otherwise stated.

xxxi While the heart is paradigmatic, the kidneys, innards and liver, are also conceived as foci for human affection and identity. See

Mark Smith (1998), "The Heart and Innards in Israelite Emotional Expressions: Notes from Anthropology and

Psychobiology" Journal of Biblical Literature, 117:3, 427-436.

xxxii Philip Michael Lasater (2015), "Law for What Ails the Heart: Moral Frailty in Psalm 86", Zeitschrift Für Die Alttestamentliche Wissenschaft 127:4, 652-668, 657-58.

xxxiii Note, however, that this in no way suggests that any particular affection is reducible to a particular physical change. For discussion of these problems see Hordern (2013), 28-30; Bound Alberti, 147-50.

xxxiv Smith, $432 \mathrm{fn} 27$.

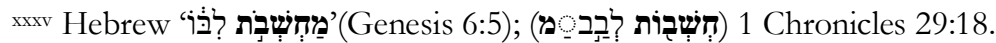

xxxvi For discussion of affective neuroscience see Hordern (2013), 34-7.

xxxvii For later rabbinic tradition, see Carol A. Newsom (2012), "Models of the Moral Self: Hebrew Bible and Second Temple Judaism", Journal of Biblical Literature 131:1, 5-25.

xxxviii William Moran (1963), "The Ancient Near Eastern Background of the Love of God in Deuteronomy", Catholic Biblical Quarterly 25:1, 77-87. 
xxxix This integration of affection with agency is reflected in classical Christian treatments of 'love' in which its intelligence is an important element: i.e. a melting fear of future dangers as opposed to a reverent, trusting fear of God indicates that love is wrongly ordered (see Augustine (1972), City of God, tr. H. Bettenson (Harmondsworth: Penguin Books), XIV.7).

${ }^{x l}$ By way of corroboration, Lapsley observed how Moses' representative friendship with God is pivotal to Deuteronomic love and the heart but inimical to Moran's apparent contrast between 'uncontrollable romantic feelings and actions'. It 'is not that Moran was wrong about the meaning of love in Deuteronomy, just that obedience is only part of the story' (Jacqueline E. Lapsley (2003), "Feeling Our Way: Love for God in Deuteronomy", The Catholic Biblical Quarterly 65:3, 350-69, 365). Thus 'the legal significance of loving God does not necessarily obviate its emotional connotations.' (ibid. 352) Going beyond Lapsley, Mirguet notes that 'the affective vocabulary of Biblical Hebrew is capacious and refers to a more extended and integrated realm of human experience than the Western concept of "emotions." (Françoise Mirguet (2019), "The Study of Emotions in Early Jewish Texts: Review and Perspectives", Journal for the Study of Judaism 50:4-5, 557-603, 563.)

xli Lasater, 658.

xlii Lasater, 658.

xliii Lasater, 660 .

xliv Lasater, 665.

xlv Lasater, 662-3.

xlvi Lasater, 663.

xlvii Lasater, 660 .

xlviii See also Jeremiah 4:4. Goldingay describes the legitimacy of a 'psychological excavation of circumcision instead of religiohistorical excavation' (John Goldingay (2000), "The Significance of Circumcision," Journal for the Study of the Old Testament 25:88, 3-18, 6).

xlix Following von Rad, Goldingay observes that 'circumcision must surely have been implicitly an act of bodily purification and dedication, otherwise it could hardly have become a metaphor for inner circumcision.' Thus 'passages which refer to metaphorical circumcision do not spiritualize what was earlier a 'merely' external rite, though they may extend the rite's inherent symbolic significance.' (Goldingay, 14).

${ }^{1}$ See Joshua Hordern (2020), Compassion in Healthcare: Pilgrimage, Practice and Civic Life (Oxford: OUP), chapter 3 for the parallel discussion of intercorporeality. See also Mauthner et al., 582-3.

li Note that the 'cord' in the umbilical cord has a quite different etymology (Greek $\chi 0 \varrho \delta \dot{\eta} /$ khordé) than the 'cor' in 'cordiality'.

lii Augustine (1972) XV.3

liii Habermas (2010), 19.

${ }^{\text {liv }}$ For discussion of Augustine's account of peregrinatio in relation to healthcare, see Hordern (2020) Implicit in pilgrimage are encounters between hearts set on different courses, between what I have called wayfarers and pilgrims (chapter 2).

lv David Albert Jones (2012), "Loss of faith in brain death: Catholic controversy over the determination of death by neurological criteria", Clinical Ethics 7:3, 133-141.

lvi Bound Alberti, 156.

lvii Mauthner et al., 549-550.

lviii Joshua Hordern (2020), "Religion, culture and conscience", Medicine 48:10 (forthcoming).

lix Miller and Truog, 71-75.

1x Robert Spaemann, Persons: The Difference between 'Someone' and 'Something', tr. O. O’Donovan. Oxford: OUP, 2007.

\section{BIBLIOGRAPHY}

Augustine. City of God. Tr. H. Bettenson. Harmondsworth: Penguin Books, 1972.

Augustine. Confessions. Tr. H. Chadwick. Oxford: OUP, 1998.

Banner, Michael C. Ethics of Everyday Life: Moral Theology, Social Anthropology, and the Imagination of the Human. Oxford: OUP, 2014.

Bound Alberti, Fay. Matters of the Heart: History, Medicine, and Emotion. Oxford: OUP, 2010.

Brock, Brian. Singing the Ethos of God: On the Place of Christian Ethics in Scripture, Grand Rapids: Eerdmans, 2007.

Brown, Peter. The Cult of the Saints : Its Rise and Function in Latin Christianity. Chicago: University of Chicago Press, 1981.

Dewar, S. and P. Boddington. "Returning to the Alder Hey Report and Its Reporting: Addressing Confusions and Improving Inquiries." Journal of Medical Ethics 30:5 (2004): 463-469.

Goldingay, John. “The Significance of Circumcision.” Journal for the Study of the Old Testament 25:88 (2000): 3-18. 
Habermas, Jurgen. The Future of Human Nature. Cambridge: Polity Press, 2003.

Habermas, Jurgen. "An Awareness of What is Missing", in An Awareness of What is Missing: Faith and Reason in a Post-Secular Age. Cambridge: Polity Press, 2010.

Hordern, Joshua. Political Affections: Civic Participation and Moral Theology. Oxford: OUP, 2013.

Hordern, Joshua. Compassion in Healthcare: Pilgrimage, Practice and Civic Life. Oxford: OUP, 2020.

Hordern, Joshua. "Religion, culture and conscience." Medicine 48:10 (2020) (forthcoming).

Jones, David. A. "Loss of faith in brain death: Catholic controversy over the determination of death by neurological criteria." Clinical Etbics 7:3 (2012): 133-141.

Lapsley, Jacqueline E. "Feeling Our Way: Love for God in Deuteronomy." The Catholic Biblical Quarterly 65:3 (2003): 350-69.

Lasater, Phillip Michael. "Law for What Ails the Heart: Moral Frailty in Psalm 86." Zeitschrift Für Die Alttestamentliche Wissenschaft 127:4 (2015): 652-668.

Mauthner, Oliver E, Enza De Luca, Jennifer M Poole, Susan E Abbey, Margrit Shildrick, Mena Gewarges, and Heather J Ross. "Heart Transplants: Identity Disruption, Bodily Integrity and Interconnectedness." Health 19.6 (2015): 578-94.

Mazrui, Ali. “The Poetics of a Transplanted Heart.” Transition 35 (1968): 51-59.

Miller, Franklin G., and Robert. Truog. Death, Dying, and Organ Transplantation : Reconstructing Medical Ethics at the End of Life, 2011.

Mirguet, Françoise. "The Study of Emotions in Early Jewish Texts: Review and Perspectives." Journal for the Study of Judaism 50:4-5 (2019): 557-603.

Moran, William. "The Ancient Near Eastern Background of the Love of God in Deuteronomy." Catholic Biblical Quarterly 25:1 (1963): 77-87.

Carol A. Newsom "Models of the Moral Self: Hebrew Bible and Second Temple Judaism”, Journal of Biblical Literature 131:1 (2012), 5-25.

Novas, Carlos and Nikolas Rose. "Genetic Risk and the Birth of the Somatic Individual." Economy and Society 29:4 (2000): 485-513.

Pormann, Peter. The Mirror of Health: discovering medicine in the golden age of Islam. London: Royal College of Physicians, 2013.

Shewmon, Alan. "The brain and somatic integration: Insights into the standard biological rationale for equating "brain death" with death." The Journal of Medicine and Philosophy, 26:5 (2001), 457-478.

Shildrick, Margrit, Andrew Carnie, Alexa Wright, Patricia Mckeever, Emily Huan-Ching Jan, Enza De Luca, Ingrid Bachmann, Susan Abbey, Dana Dal Bo, Jennifer Poole, Tammer El-Sheikh, and Heather Ross. "Messy Entanglements: Research Assemblages in Heart Transplantation Discourses and Practices." Medical Humanities 44:1 (2018): 46-54.

Smith, Mark. "The Heart and Innards in Israelite Emotional Expressions: Notes from Anthropology and Psychobiology". Journal of Biblical Literature, 117:3 (1998) 427-436. 
Spaemann, Robert. Persons: The Difference between 'Someone' and 'Something', tr. O. O’Donovan. Oxford: OUP, 2007. Spaemann, Robert, 'Is Brain Death The Death Of A Human Person?' Communio 38 (2011), 326-40.

The Royal Liverpool Children's Inquiry Report (The Redfern Report) (2001). London: The Stationery Office. 